ISSN 1392-3196 / e-ISSN 2335-8947

Zemdirbyste-Agriculture, vol. 108, No. 4 (2021), p. 331-338

DOI 10.13080/z-a.2021.108.042

\title{
Effect of biochar addition method on ammonia volatilization and quality of chicken manure compost
}

\author{
Mahmoud G. M. Abd EL-RAHIM ${ }^{1,2}$, Sen DOU ${ }^{1}$, Liu XIN ${ }^{1}$, Shuai XIE ${ }^{1}$, Ahmed SHARAF ${ }^{1}$, \\ Abdourazak ALIO MOUSSA ${ }^{3}$, Mamdouh A. EISSA ${ }^{4}$, Abdel-Rahman A. MUSTAFA ${ }^{5}$, \\ Gomaa A. M. ALI ${ }^{6}$, Mahdy H. HAMED ${ }^{7}$
}

${ }^{1}$ Jilin Agricultural University, College of Resources and Environment Sciences

Changchun 130118, Jilin, China

E-mail: dousen1959@126.com

${ }^{2}$ Al-Azhar University, Faculty of Agriculture

Assiut 71524, Egypt

${ }^{3}$ Jilin Agricultural University, Plant Biotechnology Center

Changchun 130118, Jilin, China

${ }^{4}$ Assiut University, Department of Soils and Water

Assiut 71526, Egypt

${ }^{5}$ Sohag University, Department of Soils and Water

Sohag 82524, Egypt

${ }^{6}$ Al-Azhar University, Faculty of Science

Assiut 71524, Egypt

${ }^{7}$ New Valley University, Department of Soils and Water

New Valley 72511, Egypt

\begin{abstract}
Composting chicken manure causes negative impacts on environmental ecosystem by increasing ammonia $\left(\mathrm{NH}_{3}\right)$ emissions. Split addition of maize straw-derived biochar $(\mathrm{Bi})$ during composting of chicken manure may promote the composting process, increase the quality of produced compost and reduce $\mathrm{NH}_{3}$ volatilization. To build composting piles, fresh chicken manure and maize straw were mixed $(2: 1 \mathrm{w} / \mathrm{w})$. Biochar $(10 \% \mathrm{w} / \mathrm{w}) \mathrm{was}$ applied to the compost piles in different addition modes: one-time applied biochar (OTABi), $10 \%$ at the beginning of the trial, and split-applied biochar (SABi), 2.5\% at $0,3,7$ and 15 days of the composting. In addition to the control (without biochar) treatment, measurements of $\mathrm{NH}_{3}$ emissions were performed in a bench-scale composting experiment. To evaluate the phytotoxicity and maturity of the compost, germination tests were performed in Petri dishes. Compared with the control and OTABi treatments, SABi had a great positive effect (by 40\% and 33\%) on the final general characteristics of the compost and reduced the cumulative $\mathrm{NH}_{3}$ emissions. Although OTABi treatment had faster degradation during composting, it did not enhance humification. In the mature compost, the humic substances of SABi treatment were $17 \%$ and $40 \%$ higher than control and OTABi treatments. In addition, in $\mathrm{SABi}$, the values of humic acid carbon (HAC) and humification index (HI) were significantly higher than in other treatments. By the end of composting, both biochar application modes exhibited low water-extractable organic carbon and high seed germination index compared with the control treatment.

This study suggests that during chicken manure composting split application of biochar is a crucial practice for reducing $\mathrm{N}$ loss, mitigating $\mathrm{NH}_{3}$ emissions and enhancing humification.
\end{abstract}

Key words: composting characteristics, germination index, humification, $\mathrm{NH}_{3}$ volatilization.

\section{Introduction}

The fast development in chicken farm production has generated large quantities of chicken manure resulting in significant environmental and health concerns (Wang et al., 2019). Processing of such waste using new technologies has been rapidly developing all over the world. Recently, the recycling of animal waste and post-harvest materials has been received economic and environmental attention (Sarkar et al., 2016). Composting is a useful technology based on biochemical conversion of agricultural waste into the humified

Please use the following format when citing the article:

Abd El-Rahim M. G. M., Dou S., Xin L., Xie S., Sharaf A., Alio Moussa A., Eissa M. A., Mustafa A.-R. A., Ali G. A. M., Hamed M. H. 2021. Effect of biochar addition method on ammonia volatilization and quality of chicken manure compost. Zemdirbyste-Agriculture, 108 (4): 331-338. DOI 10.13080/z-a.2021.108.042 
organic matter under aerobic conditions (Višniauskė et al., 2018; Ayilara et al., 2020). It can also reduce the mass and volume of the waste, destroy the pathogens and weed seeds and provide organic fertilizer for sustainable agriculture (Luo et al., 2014). As a process, composting can be divided into two phases: 1) biooxidative phase, which involves the mesophilic and thermophilic stages of composting process; and (2) cooling and maturation, while most of the organic matter transformations occur during the biooxidative phase (Awasthi et al., 2017).

The acceptance of chicken manure compost as a fertilizer and/or as soil amendment depends on the chemical composition and the consistent composition of the mature compost. The soil properties could be enhanced by chicken manure, where it increases organic matter content, soil nutrients, aeration, soil reaction buffering, water holding capacity, cation exchange capacity and microbial activity (Vandecasteele et al., 2014). However, adding an additive with the composting mixture has a crucial function in the biochemical transformation and maturity of compost. Biochar is a porous carbon matter produced from agricultural waste pyrolysis under limited oxygen conditions (Oni et al., 2019; Campos et al., 2020). Biochar is the common additive for accelerating decomposition reactions of composting substrates. Regardless of biochar's role as a bulking agent, amending compost with biochar is a powerful technique to reduce odours and greenhouse gaseous emissions, diminish leaching of nutrients into waterways and groundwater and conserve nutrients in the compost in forms that can help promote soil health and plant vigour.

Applying biochar with composting substrates has become common and effective (Vandecasteele et al., 2016; Awasthi et al., 2020). Biochar can enhance the performance of composting by increasing pile porosity, improving air permeability and ensuring an aerobic environment, adding more stable $\mathrm{C}$, slow-releasing biogenic elements, reducing the emitted greenhouse gases, shortening thermophilic composting stage duration, restraining odours, remediation of heavy metals and organic pollutants from the natural resources, improving composting performance and humification process as well as accelerating the microbial activities and creating a value-added product (Steiner et al., 2010; Vandecasteele et al., 2016; Liu et al., 2017). Biochar addition $(10 \%)$ leads to compost formation with better chemical and biochemical characteristics, as it enhances degradation rate and the sorption of labile compounds into the biochar (Jindo et al., 2012). In addition, biochar has also been used to reduce $\mathrm{NH}_{3}$ volatilization, enhance the humification process during composting and increase the stability of the final product (Dias et al., 2010; Jindo et al., 2016; Xiao et al., 2017). Jindo et al. (2016) reported that mixing biochar with poultry manure at the beginning of the composting improved the final compost and the composition of the organic matter fractions. The chemistry of biochar during composting depends on the characteristics of biochar raw material, pyrolysis conditions, application rate and application mode (Vandecasteele et al., 2016; Xiao et al., 2017). The recommended application level of biochar that can accelerate organic matter decomposition ranged from 5\% to $10 \%$ dry weight basis (Liu et al., 2017; Akdeniz, 2019). In contrast, the addition of excess amounts $(>20 \%)$ of biochar may interfere with organic waste biodegradation (Liu et al., 2017). Biochar has been used as an additive at the beginning of composting or blending with mature compost (Vandecasteele et al., 2016).

Several studies have been focused on the effect of blending biochar with the composting mixture on $\mathrm{NH}_{3}$ emissions and organic matter degradation. However, there is a shortage of the available reports concerning the impact of biochar application mode on the $\mathrm{NH}_{3}$ volatilization, decomposition and humification of composting organic matter. We assume that the split addition of biochar during composting may cause changes in the surface properties of biochar and promote the composting process.

This research aimed to study: (1) the effect of different application modes of maize straw biochar on the composting characteristics of chicken manure; (2) the changes in the number of humic substances, e.g., humic and fulvic acids fractions during the composting; (3) the impact of biochar application mode on the mitigation of ammonia $\left(\mathrm{NH}_{3}\right)$ emissions during the composting process; (4) the effect of biochar application mode on the quality and maturity of the produced compost.

\section{Materials and methods}

Composting feedstocks. Fresh chicken faeces were collected from a caged chicken farm located under a continuous egg production system in the Experimental Station of Jilin Agricultural University, Jilin province, Northwest of China. Maize straw was collected from the experimental field in the summer season of 2018. To obtain pieces with a length of $1-5 \mathrm{~cm}$, maize straw was air-dried and chopped. Maize straw-derived (fine particles $<2 \mathrm{~mm}$ ) biochar (Bi) was purchased from Liaoning Jinhefu Agricultural Science and Technology Co. Ltd., China. Biochar was manufactured by pyrolysis of maize straw at $300-400^{\circ} \mathrm{C}$ temperature under limited oxygen conditions. The composting experiment was performed in June 2018 at the experimental field $\left(43^{\circ} 49^{\prime} 5^{\prime \prime} \mathrm{N}, 125^{\circ} 24^{\prime} 8^{\prime \prime} \mathrm{E}\right)$ of Jilin Agricultural University, Jilin Province, Changchun city, Northeast of China. The soil in the experiment zone was classified as Chernozem (WRB, 2014; Zádorová et al., 2021), and its characteristics were: acidity (pH) 7.2, available nitrogen $(\mathrm{N}) 132.23 \mathrm{mg} \mathrm{kg}^{-1}$, phosphorus $\left(\mathrm{P}_{2} \mathrm{O}_{5}\right)$ $18.56 \mathrm{mg} \mathrm{kg}^{-1}$ and potassium $\left(\mathrm{K}_{2} \mathrm{O}\right) 98.42 \mathrm{mg} \mathrm{kg}^{-1}$. The selected physical and chemical properties of composting feedstocks are shown in Table 1.

Composting start-up. The composting treatments were one-time applied biochar (OTABi), split-applied biochar (SABi) and without biochar (control). Each composting pile had dimensions of $1.20 \mathrm{~m}$ length $\times 1 \mathrm{~m}$ width $\times 0.8 \mathrm{~m}$ height with a total volume of $0.95 \mathrm{~m}^{3}$. Each pile consisted of $170 \mathrm{~kg}$ of fresh chicken faeces mixed with $43 \mathrm{~kg}$ of air-dried maize straw at a ratio of 1:2 dry weight basis representing the composting mixture. Each pile was treated with $10 \%$ of biochar as follows: OTABi $-10 \%$ biochar one-time that was blended with the composting mixture at the beginning of the composting, SABi $2.5 \%$ in four doses that were mixed with the composting materials at $0,3,7$ and 15 days and no biochar was added (Liu et al., 2017). The composting piles were turned manually every three days during the first week and then once every two weeks up to the end of the experiment (65 days). During the composting process, the temperatures of the pile were continuously recorded every hour using a temperature logger ZDR-11 (Hangzhou Zeda Instrument Co. Ltd., China). To monitor the biological activity, the thermocouple probe was inserted into the centre of the pile at a depth of $30 \mathrm{~cm}$. During the process, the moisture content of each pile treatment periodically was adjusted to $55-60 \%$ (Jindo et al., 2016). When the temperature of all piles decreased to the ambient, the compost was considered mature. All composted piles lasted for 65 days.

Sampling and chemical analysis. After turning the composting piles, to obtain a composite sample $(\sim 700 \mathrm{~g})$, three sub-samples from the top, bottom and middle of the pile were collected and homogenized at $0,3,7,15$, 30,45 and 65 days of composting. Each composite 
Table 1. Physical and chemical properties and elemental composition of composting raw materials and biochar

\begin{tabular}{lccccccccccc}
\hline \multirow{2}{*}{ Substrate } & $\mathrm{pH}$ & $\mathrm{EC}$ & $\mathrm{C}$ & $\mathrm{N}$ & $\mathrm{H}$ & $\mathrm{HAC}$ & $\mathrm{FAC}$ & $\mathrm{C}: \mathrm{N}$ & $\mathrm{OM}$ & $\mathrm{MC}$ \\
\cline { 7 - 12 } & $(1: 10)$ & $\mathrm{dS} \mathrm{cm}-1$ & & $\%$ & & & $\mathrm{~g} \mathrm{~kg}^{-1}$ & & & $\%$ \\
\hline \multirow{2}{*}{ Chicken faeces } & 6.55 & 2.56 & 27.00 & 6.20 & 3.80 & 21.00 & 27.10 & 4.51 & 48.01 & 73.20 \\
& \pm 0.00 & \pm 0.04 & \pm 2.02 & \pm 0.11 & \pm 0.03 & \pm 1.16 & \pm 2.67 & \pm 0.32 & \pm 3.22 & \pm 3.30 \\
\hline \multirow{2}{*}{ Maize straw } & 5.40 & 1.65 & 40.99 & 1.00 & 3.90 & 53.01 & 57.00 & 39.00 & 71.23 & 8.01 \\
& \pm 0.00 & \pm 0.00 & \pm 3.14 & \pm 0.03 & \pm 0.04 & \pm 3.55 & \pm 3.55 & \pm 3.72 & \pm 4.14 & \pm 0.02 \\
\hline \multirow{2}{*}{ Biochar } & 9.88 & 1.31 & 59.02 & 1.20 & 1.80 & 9.02 & 4.10 & 51.42 & 102.00 & 20.00 \\
& \pm 0.01 & \pm 0.00 & \pm 3.04 & \pm 0.03 & \pm 0.01 & \pm 0.60 & \pm 0.54 & \pm 3.20 & \pm 4.17 & \pm 2.00 \\
\hline
\end{tabular}

EC - electrical conductivity, C - carbon, $\mathrm{N}$ - nitrogen, $\mathrm{H}$ - hydrogen, HAC - humic acid carbon, FAC - fulvic acid carbon, C:N - carbon to nitrogen ratio, $\mathrm{OM}$ - organic matter, $\mathrm{MC}$ - moisture content; \pm values mean standard deviations $(\mathrm{n}=3$ replicates $)$

sample was divided into two parts. The first part was immediately stored at $4^{\circ} \mathrm{C}$ temperature for phytotoxicity assessment; the other was air-dried, glandered and then passed through a $0.250 \mathrm{~mm}$ sieve for chemical analyses and humic substances determinations. Humic substances are mainly heterogeneous compounds derived from the complexation of carbonaceous components such as lignin, carbohydrates and amines.

The acidity $(\mathrm{pH})$ was determined in a suspension of $1: 10(\mathrm{w} / \mathrm{v})$ dry weight basis compost to deionized water ratio after shaking for $1 \mathrm{~h}$, equilibrium for $1 \mathrm{~h}$ and then centrifuged at $3500 \mathrm{rpm}$ for 15 minutes. Electrical conductivity (EC) was determined in a filtrate solution of 1:10 (w/v) by EC meter apparatus. Water extractable organic carbon (WEOC) was determined in 1:10 (w/v) water extract using a total organic carbon $\left(\mathrm{C}_{\text {tot }}\right)$ analyser TOCVCSN (Shimadzu, Japan). The elemental composition of the raw material was measured using an analyser (Elemental Analyser GmbH Inc., Germany).

Extraction of humic substances (HSs). HSs were extracted by the International Humic Substances Society (IHSS) recommended method for extracting the HSs from natural organic sources. In brief, $1 \mathrm{~g}$ of $0.250 \mathrm{~mm}$ dried sample plus $30 \mathrm{ml}$ of alkaline mixture solution $\left(0.1 \mathrm{M} \mathrm{NaOH}+0.1 \mathrm{M} \mathrm{Na}_{4} \mathrm{P}_{2} \mathrm{O}_{7}\right.$ at $\left.\mathrm{pH} \sim 14\right)$ were filled into a $100 \mathrm{ml}$ centrifuge tube and shook at $145 \mathrm{rpm}$ for $1 \mathrm{~h}$ under inert gas $\left(\mathrm{N}_{2}\right)$ conditions. Then the suspension was centrifuged at $3500 \mathrm{rpm}$, filtered through $0.45 \mu \mathrm{m}$ filter paper and transferred into a $50 \mathrm{ml}$ volumetric flask. The residual solid sample was washed with $20 \mathrm{ml}$ of the same alkaline mixture, then centrifuged and filtered. After that, to complete the volume to $50 \mathrm{ml}$, it was transferred into the same flask. From the extracted HSs solution, $30 \mathrm{ml}$ were acidified by $12 \mathrm{M} \mathrm{HCl}$ at $\mathrm{pH} 1$ overnight to precipitate humic acid (HA) fraction. After filtration through $0.45 \mu \mathrm{m}$ filter paper, the coagulated part represented HA, while the supernatant represented the fulvic acid (FA) fraction. The HA part was dissolved in hot solution $0.05 \mathrm{M} \mathrm{NaOH}$ and transferred into a $50 \mathrm{ml}$ volumetric flask. As well, FA was completed by $0.05 \mathrm{~N} \mathrm{H}_{2} \mathrm{SO}_{4}$ into a $50 \mathrm{ml}$ volumetric flask. Finally, the potassium dichromate method determined HSs and HA carbon content, while FA was measured by analyser TOC-VCSN analyser (Shimadzu, Japan).

Humification index (HI) was calculated from the alkali extracts (HSs and HA) as follows:

$$
H I=\left(\frac{H S s}{\text { Ctot }}\right) \times 100 \text { (Volungevičius et al., 2019) (1); }
$$
percentage of HA PHA $=\left(\frac{H A}{H S s}\right) \times 100(2)$; and degree of polymerization $D P=\left(\frac{H A}{F A}\right)$ (Iqbal et al., 2015) (3).

Germination index $(G I)$ was used to estimate phytotoxicity and maturity of the compost (Buhaiov et al., 2018). Twenty seeds of Chinese cabbage were sown in sterilized Petri dishes that contained $10 \mathrm{ml}$ of the water extract $(1: 10)$ of the mature compost and covered by Whitman filter paper. The experiment was conducted at $25^{\circ} \mathrm{C}$ temperature for 3 days in the dark (Zhang, Sun, 2016). Germination index (GI) was calculated using the following equation (Tiquia et al., 1996):

$$
\mathrm{GI}=(\mathrm{SGS} \times \mathrm{RLS}) /(\mathrm{SGC} \times \mathrm{RLC}) \times 100,
$$

where SGS is the seed germination of the sample (\%), RLS - the root length of the sample (mm), SGC - the seed germination of control (\%), RLC - the root length of control ( $\mathrm{mm})$.

Measurements of ammonia $\left(\mathrm{NH}_{3}\right)$ emissions. To establish the effect of biocharadditionmode on $\mathrm{NH}_{3}$ emissions, a bench-scale composting experiment was carried out for 28 days at $25 \pm 0.5^{\circ} \mathrm{C}$ temperature to control the measured parameters. The same treatments (OTABi, SABi and control) that used in the windrow composting system were conducted in glass vessels (Nakhshiniev et al., 2014). Each glass vessel was contained $60 \mathrm{~g}$ (32 g chicken manure $+18 \mathrm{~g}$ maize straw), and the vessels were treated with OTABi, $\mathrm{SABi}$ or without biochar (control). The volatilized $\mathrm{NH}_{3}$ was briefly trapped in $2 \% \mathrm{~B}(\mathrm{OH})_{3}$ (boric acid) solution, then titrated with $0.05 \mathrm{M} \mathrm{HCl}$ (hydrochloric acid). The composting treatments were studied in 5 replicates. The concentrations of $\mathrm{NH}_{3}$ trapped emissions were measured via the titration method (Martins et al., 2021).

Statistical analysis. The collected data were checked by Kolmogorov-Smirnov (K-S) (Chakravarti et al., 1967) for normality before the analysis of variance (ANOVA) test, and no changes were needed. The statistical analysis was performed using the software Minitab, version 17.3.1 (Informer Technologies Inc.). The significant differences between treatments were tested via ANOVA and completed by Tukey test at $p<0.05$ significance level. For data analysis and drawing, software OriginPro, version 8.5 SR1 (Origin Lab Corporation, USA) was used.

\section{Results}

Effect of biochar application mode on the characteristics of composting. The temperature behaviour of the composting piles is shown in Figure 1. At the beginning of composting, the temperature increased slowly for all the treatments until they reached the thermophilic stage after two days. During the process, the maximum recorded temperatures in OTABi, SABi and control treatments were $73.5,66.5$ and $68.20{ }^{\circ} \mathrm{C}$, respectively. The highest temperatures were observed in SABi treatment.

At the beginning of composting, the initial $\mathrm{pH}$ values in $\mathrm{SABi}$ and control treatments were proportionally neutral (6.76 and 7.08), but OTABi exhibited a slightly alkaline $\mathrm{pH}$ (8.48). During the biooxidative phase, the measured $\mathrm{pH}$ values increased in all the treatments 


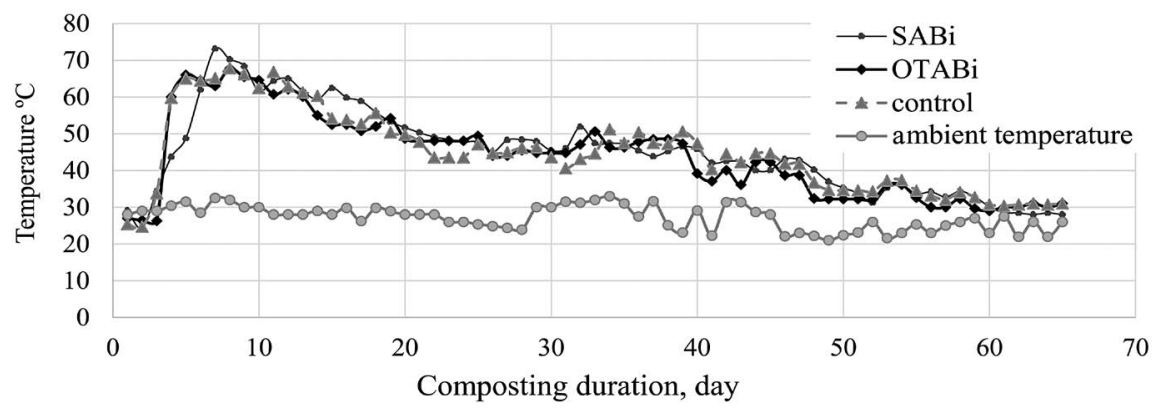

Note. Error bars show the standard deviation of 5 replicates.

Figure 1. Temperature behaviour of the composting piles split-applied (SABi), one-time applied (OTABi) and without biochar (control)

and reached the maximum values by day 14 with 9.06 and 9.30 for SABi and OTABi, respectively, while the control treatment reached 8.81 by 30 days. The measured $\mathrm{pH}$ values revealed high significant variations $(p<$ $0.01)$ between the various addition modes of biochar (Figure 2A). By the time, $\mathrm{pH}$ values of all the treatments were slightly decreased after day 30, except for the OTABi treatment. At the end of composting (65 days), both biochar application modes exhibited somewhat

A

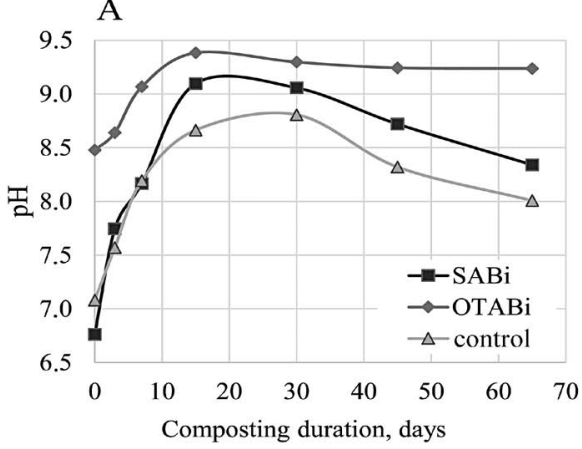

alkaline $\mathrm{pH}$ values. Although the $\mathrm{SABi}$ treatment had alkaline $\mathrm{pH}$ values $(8.34)$, it was by $0.9 \mathrm{pH}$ unit lower than in the OTABi treatment (9.24). The lowest $\mathrm{pH}$ value (8.00) showed the control treatment.

Electrical conductivity (EC) of compost can reflect its validity as an amendment for soil fertility and agricultural production. As shown in Figure 2B, the initial $E C$ values were $4.72,3.54$ and $4.26 \mathrm{dS} \mathrm{cm}^{-1}$ for $\mathrm{SABi}, \mathrm{OTABi}$ and control treatments, respectively.

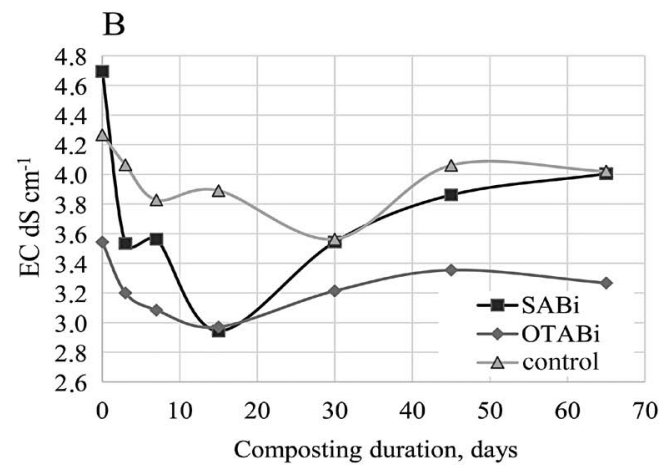

Note. Error bars show the standard deviation of 5 replicates.

Figure 2. The acidity (pH) (A) and electrical conductivity (EC) (B) behaviour of the split-applied (SABi), one-time applied (OTABi) and without biochar (control) during composting

Effect of biochar addition mode on the content of humic substances (HSs). The active fractions of HSs are HA and FA. The carbon contents of HSs, HA and FA are illustrated in Figure 3A-C. At the initial stage, SABi and control treatments showed high initial contents (97.10 and $95.13 \mathrm{~g} \mathrm{~kg}^{-1}$, respectively) of HSs carbon, while OTABi demonstrated the lowest initial HSs $\left(69.88 \mathrm{~g} \mathrm{~kg}^{-1}\right)$.

As shown in Figure 3B, the initial concentrations of HA showed relatively similar values for SABi and control treatments, while OTABi had the lowest initial concentration of HA. During the composting process, the carbon content of HA degraded gradually during the first 30 days and then relatively increased only in the SABi treatment. In contrast, HA remained constant in OTABi and control treatments until the end of composting. The FA concentration dramatically declined in both biochar application modes and the control treatment during the first four weeks of composting (Figure 3C). After 30 days of composting, all the treatments exhibited proportionally stable FA values until the end of the process.

Effect of biochar application mode on compost quality. Degree of polymerization (HA to FA ratio), humification index (HI), percentage of HA (PHA) and water extractable organic carbon (WEOC) were used as useful indexes to evaluate compost stability and maturity.

During the experiment, the HA:FA periodically increased for both biochar application modes and control treatment. After 45 days of composting, the HA:FA revealed stable values for all biochar application modes, and it did not change until the end of composting. By the end of the composting process, SABi had a higher HA:FA, while control treatment had the lowest one. In addition, a significantly higher $(p<0.05)$ HA:FA had SABi than OTABi. The changes of HI and PHA for both biochar application modes and control treatments are shown in Table 2. In general, both OTABi and SABi application modes exhibited an increase in HI and PHA during the composting compared with the control treatment. At the mature compost, SABi had significantly higher $(p<0.05)$ $\mathrm{HI}$ and PHA rates than other treatments.

Water extractable organic carbon (WEOC) represents the favourable carbon source for microbes and is considered an operational parameter for assessing compost maturity. As shown in Figure 3D, the concentration of WEOC increased from day 0 to 3 in $\mathrm{OTABi}$, whereas the increase extended to 7 days in SABi and control treatments. After the short increase, all the WEOC in all the treatments sharply decreased until day 30 , and then they showed unchanged values up to the end of the composting.

Germination index (GI) is an effective test to assess the validity of compost. In addition, the relative root elongation is also a suitable parameter to evaluate the maturity of compost. Chinese cabbage seeds were used to investigate the toxicity of compost. In the present 


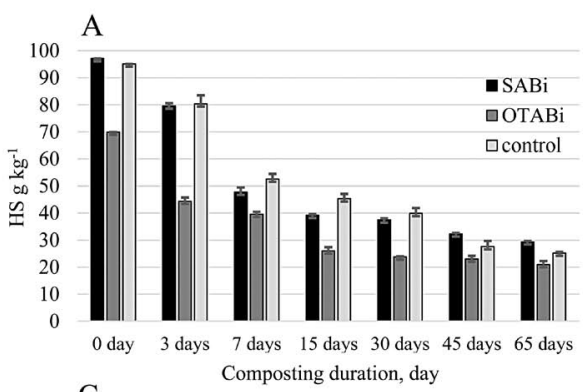

B
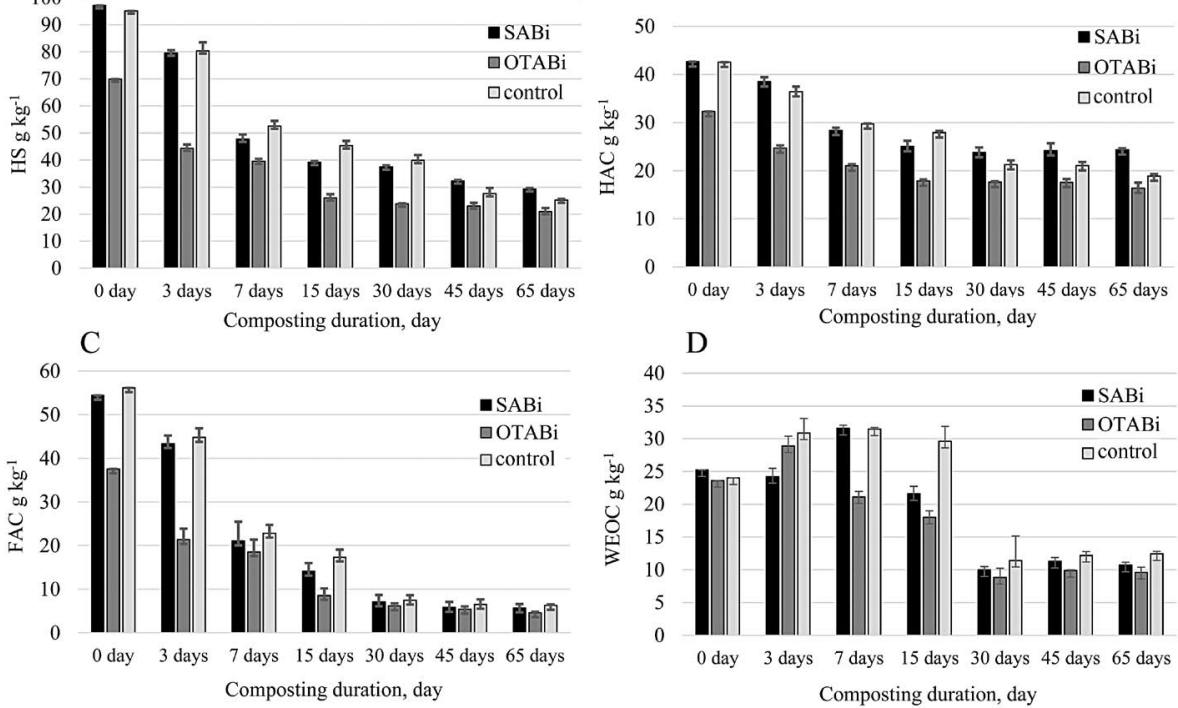

Note. Error bars show the standard deviation of 5 replicates; means in the same column followed by the same letter are not significantly different.

Figure 3. The effect of split-applied (SABi), one-time applied (OTABi) and without biochar (control) on changes in humic substances (HSs) (A), humic acid carbon (HAC) content (B), fulvic acid carbon (FAC) (C) and waterextractable organic carbon (WEOC) (D) during composting

Table 2. Effect of biochar application mode on humification index, percentage of humic acid (HA) and humic to fulvic acid (FA) ratio as quality parameters of the compost

\begin{tabular}{|c|c|c|c|}
\hline $\begin{array}{c}\text { Time, } \\
\text { day }\end{array}$ & $\begin{array}{l}\text { Humification } \\
\text { index }\end{array}$ & $\begin{array}{c}\text { Percentage of } \\
\text { HA }\end{array}$ & $\begin{array}{l}\text { HA to FA } \\
\text { ratio }\end{array}$ \\
\hline \multicolumn{4}{|c|}{ Split-applied biochar (SABi) } \\
\hline 0 & $13.02 \pm 0.44 \mathrm{a}$ & $43.95 \pm 1.35 \mathrm{a}$ & $0.78 \pm 0.04 \mathrm{a}$ \\
\hline 3 & $13.94 \pm 0.14 \mathrm{a}$ & $48.42 \pm 1.53 \mathrm{~b}$ & $0.90 \pm 0.10 \mathrm{a}$ \\
\hline 7 & $13.54 \pm 0.52 \mathrm{a}$ & $59.54 \pm 2.39 \mathrm{a}$ & $1.35 \pm 0.06 \mathrm{a}$ \\
\hline 15 & $14.62 \pm 0.87 \mathrm{a}$ & $63.99 \pm 3.56 \mathrm{ab}$ & $1.80 \pm 0.29 \mathrm{a}$ \\
\hline 30 & $16.90 \pm 1.62 \mathrm{~b}$ & $63.54 \pm 3.94 b$ & $3.46 \pm 0.91 \mathrm{a}$ \\
\hline 45 & $22.21 \pm 0.61 \mathrm{a}$ & $74.85 \pm 0.33 \mathrm{~b}$ & $4.23 \pm 0.71 \mathrm{a}$ \\
\hline 65 & $23.01 \pm 0.78 \mathrm{a}$ & $82.98 \pm 4.27 \mathrm{a}$ & $4.28 \pm 0.16 \mathrm{a}$ \\
\hline \multicolumn{4}{|c|}{ One-time applied biochar (OTABi) } \\
\hline 0 & $10.35 \pm 0.21 \mathrm{c}$ & $44.78 \pm 0.56 \mathrm{a}$ & $0.84 \pm 0.04 \mathrm{a}$ \\
\hline 3 & $11.42 \pm 0.08 b$ & $55.76 \pm 0.84 \mathrm{a}$ & $1.17 \pm 0.16 \mathrm{a}$ \\
\hline 7 & $11.78 \pm 0.07 b$ & $53.16 \pm 2.45 \mathrm{~b}$ & $1.14 \pm 0.11 \mathrm{a}$ \\
\hline 15 & $12.52 \pm 0.00 \mathrm{~b}$ & $68.80 \pm 1.16 \mathrm{a}$ & $2.10 \pm 0.14 \mathrm{a}$ \\
\hline 30 & $19.14 \pm 0.77 \mathrm{a}$ & $74.06 \pm 1.69 \mathrm{a}$ & $2.87 \pm 0.25 \mathrm{a}$ \\
\hline 45 & $19.27 \pm 0.98 b$ & $76.43 \pm 0.97 \mathrm{a}$ & $3.25 \pm 0.18 \mathrm{a}$ \\
\hline 65 & $18.66 \pm 0.34 b$ & $78.16 \pm 1.36 \mathrm{~b}$ & $3.59 \pm 0.28 b$ \\
\hline \multicolumn{4}{|c|}{ Without biochar (control) } \\
\hline 0 & $11.94 \pm 0.18 b$ & $38.78 \pm 2.02 \mathrm{~b}$ & $0.66 \pm 0.04 \mathrm{~b}$ \\
\hline 3 & $11.30 \pm 0.09 \mathrm{~b}$ & $45.36 \pm 1.11 \mathrm{c}$ & $0.81 \pm 0.04 \mathrm{a}$ \\
\hline 7 & $11.94 \pm 0.39 b$ & $56.63 \pm 1.89 a b$ & $1.31 \pm 0.10 \mathrm{a}$ \\
\hline 15 & $15.37 \pm 0.35 \mathrm{a}$ & $61.69 \pm 0.92 b$ & $1.61 \pm 0.06 \mathrm{a}$ \\
\hline 30 & $14.77 \pm 0.25 \mathrm{c}$ & $53.51 \pm 4.59 \mathrm{c}$ & $2.88 \pm 0.36 \mathrm{a}$ \\
\hline 45 & $18.34 \pm 0.56 b$ & $76.38 \pm 0.74 \mathrm{a}$ & $3.24 \pm 0.13 \mathrm{a}$ \\
\hline 65 & $20.22 \pm 0.53 b$ & $75.09 \pm 1.92 \mathrm{~b}$ & $3.03 \pm 0.30 b$ \\
\hline
\end{tabular}

Note. \pm values mean standard deviations ( $\mathrm{n}=3$ replicates); small letters mean the significant difference at 0.05 level.

study, the GI of Chinese cabbage seeds that were sown in the water extract $(1: 10)$ of fresh mature compost was $94.49,78.63$ and $73.37 \%$ for SABi, OTABi and control treatments, respectively (Figure 4). The highest GI value was observed in the SABi treatment.

Effect of biochar application mode on the mitigation of ammonia emissions. The daily and cumulative $\mathrm{NH}_{3}$ emissions from both biochar application modes under the bench-scale composting experiment are shown in Figure 5.

The daily $\mathrm{NH}_{3}$ emissions increased during the first 9 days in the SABi and OTABi treatments, while the control treatment recorded an increase in ammonia emissions over 18 days (Figure 5A). The highest $\mathrm{NH}_{3}$ emissions were observed in the control treatment. Although both biochar application modes decreased

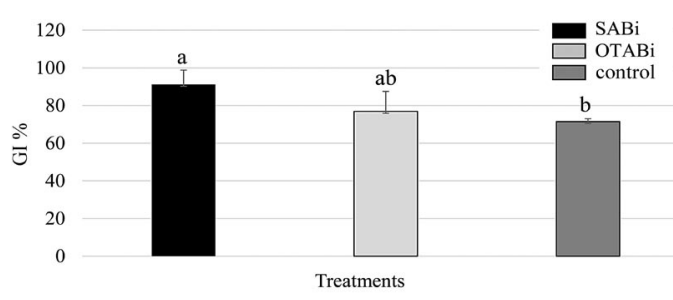

Note. Error bars show the standard deviation of 5 replicates; means in the same column followed by the same letter are not significantly different.

Figure 4. Effect of split-applied (SABi), one-time applied (OTABi) and without biochar (control) on germination index (GI) of the mature compost 
$\mathrm{NH}_{3}$ emissions, the SABi treatment had the lowest $\mathrm{NH}_{3}$ emissions. The crucial period for monitoring $\mathrm{NH}_{3}$ emissions occurred mainly between 4 to 8 days of composting. In addition, the minimum cumulative $\mathrm{NH}_{3}$ (32.6 mg kg-1) was observed in the SABi treatment, which presented the addition of biochar in small doses

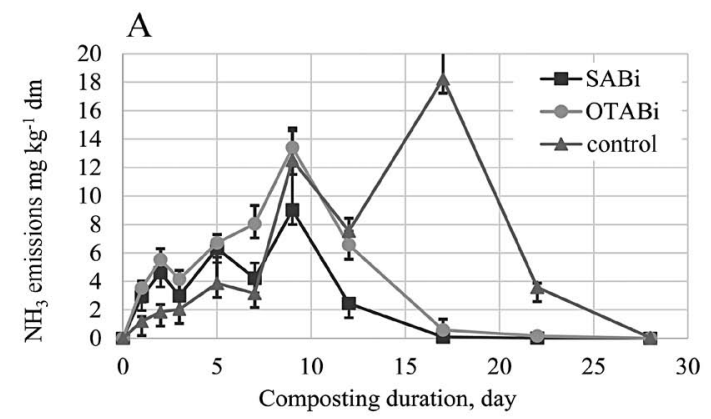

Note. Error bars show the standard deviation of 5 replicates. at a different time during composting (Figure 5B). In contrast, the control treatment had the maximum cumulative $\mathrm{NH}_{3}$ emissions $\left(54.0 \mathrm{mg} \mathrm{kg}^{-1}\right)$. Moreover, the $\mathrm{SABi}$ treatment reduced the cumulative $\mathrm{NH}_{3}$ emissions by $40 \%$ and $33 \%$ compared with the control and OTABi treatments, respectively.

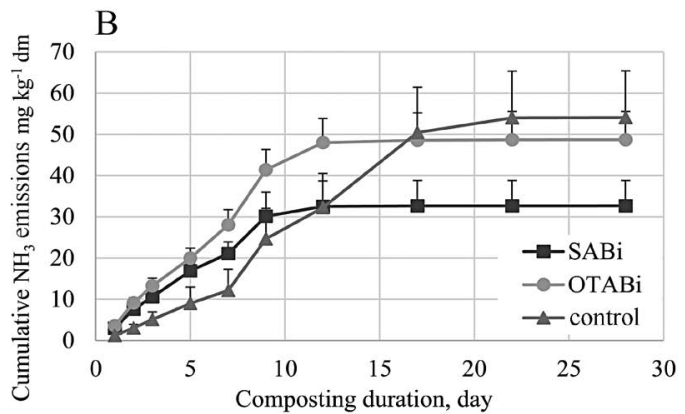

Figure 5. Effect of split-applied (SABi), one-time applied (OTABi) and without biochar (control) on the daily (A) and cumulative $(\mathrm{B})$ ammonia $\left(\mathrm{NH}_{3}\right)$ emissions

\section{Discussion}

Effect of biochar application mode on the quality of compost. To evaluate compost stability and maturity, degree of polymerization (HA to FA ratio), humification index (HI), percentage of HA (PHA) and water extractable organic carbon (WEOC) as useful indexes have been widely used. In the present study, both OTABi and SABi treatments increased the quality indicators over the control treatment. Germination index (GI) of Chinese cabbage seeds was 94, 78 and $73 \%$ for SABi, OTABi and control treatments, respectively. When GI reached $50 \%$, the compost was regarded as mature and no longer phytotoxic. Regarding this limitation of maturity, all the tested treatments reached GI values greater than $50 \%$, and the compost was considered phytotoxin-free. In addition, SABi had significantly higher $(p<0.05)$ GI than control and OTABi treatments suggesting that the biochar application mode affected compost maturity.

The functional role of biochar addition is to promote the decomposition of organic matter. Moreover, it can sorb the easily degradable, i.e., dissolved organic (DOC) carbon (Anyika et al., 2014). Furthermore, biochar promoted microbial activities by alleviating several inhibitors $\left(\mathrm{NH}_{3}, \mathrm{NH}_{4}^{+}, \mathrm{H}_{2} \mathrm{~S}\right.$ or $\left.\mathrm{SO}_{4}{ }^{2-}\right)$ generated during composting (Vandecasteele et al., 2016). Regarding compost stability, WEOC content has a negative trend with stability of the organic matter fractions. Both biochar application modes exhibited high mature compost, while the treatment without biochar was the lowest quality. The higher degradation of DOC in biochar treated piles is clearly due to the biochar substrate or its surface property that stimulated microbial activity (Khan et al., 2014).

The total addition of biochar at the beginning of composting may cause clogging of the applied biochar's hydrophilic microspores via composting moisture and become less effective in complexation with the produced organic acids that are released during the composting. On the other hand, when biochar is applied in split doses during the active phase, the applied biochar's interior and exterior functional groups have greater chances to be physically activated through the composting gasses and heat. These activated surfaces can easily interact with the produced humic acids fraction result in complexation and more stable compounds. Moreover, the SABi had the highest polymerization degree due to the application of fresh biochar, which had more ability to react with humified matter and produce more stable materials. The hard-wood biochar-amended poultry manure compost enhanced the humification process (Jindo et al., 2016). It has been observed that the HA:FA was significantly higher in biochar treatments than in treatment without biochar (Awasthi et al., 2017). Similar results were also reported in the literature (Dias et al., 2010).

Effect of biochar application mode on the mitigation $\mathbf{N H}_{3}$. The crucial period of monitoring $\mathrm{NH}_{3}$ emissions occurred between 4 to 8 days of composting (Li et al., 2012). The main reason for the $\mathrm{NH}_{3}$ loss through the volatilization mechanism is that it raises the composting mixture's acidity $(\mathrm{pH})$ and temperature. The total addition of alkaline biochar $(10 \%)$ at the beginning of composting raised the pile $\mathrm{pH}$ and caused significant increases in the $\mathrm{NH}_{3}$ emissions. At the beginning of composting, the initial $\mathrm{pH}$ values in SABi and control treatments were proportionally neutral, but in OTABi exhibited a slightly alkaline $\mathrm{pH}$. These highest $\mathrm{pH}$ values in all composting treatments are in line with the rising temperature and probably are due to the decomposition of polyproteins into $\mathrm{NH}_{3}$ (Qasim et al., 2018).

In the $\mathrm{SABi}$ application mode, the evaporated gasses and water vapor (as gasification agents) could activate and accelerate the surface oxidation of biochar particles, and the number of carboxylic groups attached to the surface biochar will be increased (Feng et al., 2018). Such carboxylic groups could decrease composting $\mathrm{pH}$ (Basso et al., 2013). During the first 7 days, the EC values declined drastically, then slightly increased in both biochar application modes. The drop in EC values may be due to $\mathrm{NH}_{3}$ volatilization and mineral salt precipitation (Gao et al., 2010). In contrast, the EC increment during the biooxidative and maturity phases could be attributed to the release of mineral salts through the decomposition of organic materials as well as the existence of soluble chemical salts such as potassium, sodium and chlorine as the result of the mixing of solid and liquid fractions (Silva et al., 2009). At the end of the composting period, all treatments had EC values less than $4 \mathrm{dS} \mathrm{cm}^{-1}$ indicating a good quality of the final product. This type of activation might increase the efficiency of biochar as an absorbent agent for the mitigation of $\mathrm{NH}_{3}$ emissions. Application of pine chip biochar ( $20 \%$ fresh weight) to poultry litter reduced the total $\mathrm{NH}_{3}$ and $\mathrm{N}$ losses by $64 \%$ and $52 \%$, respectively (Steiner et al., 2010).

At the beginning of the composting process, the biochar addition leads to a faster decomposition rate in the biooxidative phase and lower greenhouse gas emissions (Awasthi et al., 2016). Moreover, biochar can reduce nitrogen loss via the absorption of $\mathrm{NH}_{3}$ gaseous and watersoluble $\mathrm{NH}_{4}$ (Rong et al., 2019). On the other side, the specific composting conditions of poultry manure-blended biochar, which are characterized by high temperatures and high $\mathrm{pH}$ values (above 8), favoured the volatilization of 
the $\mathrm{NH}_{3}$ rather than the adsorption process on the particle surface (Dias et al., 2010). In addition, the mixing of biochar with the composting mixture at the beginning of composting enhanced the community of nitrifying and denitrifying bacteria, which can degrade aromatic compounds (Zainudin et al., 2020). Therefore, further biological studies are recommended to be carried out.

In this study, the main improvements to the composting system achieved by dividing the amount of biochar into small doses to the feedstock mixtures are: (1) mitigation of the alkaline effect of biochar during the biooxidation stage, which is the main factor causing nitrogen loss; (2) minimization of the $\mathrm{NH}_{3}$ volatilization by $40 \%$ and $30 \%$ compared to those of control and OTAB treatments, respectively; and (3) the adopted measures, which are often used to describe humification and compost stability clarified the significant superiority of the SABi.

\section{Conclusions}

1. The biochar (Bi) application mode can significantly affect the composting process and the quality of obtained compost. One-time applied biochar (OTABi) accelerated the organic matter degradation but did not promote humic acid (HA) formation, whereas the split-applied biochar (SABi) reduced the total nitrogen loss greater than the OTABi mode.

2. In addition, dividing biochar in equal doses at different times during the thermophilic phase reduced the cumulative $\mathrm{NH}_{3}$ emissions by $40 \%$ and $33 \%$ compared with the control and OTABi treatments, respectively. Moreover, the adopted measures used to describe humification and compost stability clarified the SABi significance superiority.

3. The obtained results showed that dividing the amount of applied biochar into small equal doses during the biooxidative stage of composting can reduce the alkaline effect of the biochar. Therefore, SABi application is the best strategy to maximize humification during chicken manure composting and mitigate nitrogen loss.

Inclusive studies are required to investigate the effect of biochar application modes on nutrient availability during composting.

\section{Acknowledgments}

This study was funded by the National Key Research and Development Program of China (2017YFD0200601), the National Key Research and Development Program of China (2017YFD0200801) and the Innovative Research Group Project of the National Natural Science Foundation of China (41571231).

Received 20012021

Accepted 25072021

\section{References}

Akdeniz N. 2019. A systematic review of biochar use in animal waste comnosting Waste Management 88: 291-300. https://doi.org/10.1016/j.wasman.2019.03.054

Anyika C., Abdui Majid Z., Ibrahim L., Zakaria M. P. Yahya A. 2014. The impact of biochars on sorption and biodegradation of polycyclic aromatic hydrocarbons in soils - a review. Environmental Science and Pollution Research 27 (5): 3214-3241 https://doi.org/10.1007/s11356-014-3719-5

Awasth1 M. K., Wang Q., Ken X., Zhao J., Huang H., Awasthi S. K., Lahori Ä. H., Li R., Zhou L., Zhang Z. 2016. Role of biochar amendment in mitigation of nitrogen loss and greenhouse gas emission during sewage sludge comnosting Rinresnurce Terhnolngy, ?19: 770-280. https://doi.org/10.1016/j.biortech.2016.07.128

Awasth1 M. K., Wang Q., Chen H., Wang M., Ken X., Zhao J., Li J., Guo D., Li D. S., Awasthi S. K., Sun X., Zhang Z. 2017. Evaluation of biochar amended biosolids co-composting to improve the nutrient transformation and its correlation as a function for the production of nutrient-rich compost. Rinresourre Terhnolnov 337.156-166 https://doi.org/10.1016/j.biortech.2017.01.044
Awasthi M. K., Duan Y., Awasthi S. K., Liu T., Zhang Z. 2020. Effect of biochar and bacterial inoculum additions on cow dung composting. Rioresource Technology, 297: 122407. https://doi.org/10.1016/j.biortech.2019.122407

Ayilara M. S., Ulanrewaju U. S., Babalola U. U., Odeyemi O. 2020. Waste management through composting: challenges and notentials. Sustainahility, 12 (11): 4456. https://doi.org/10.3390/su12114456

Basso A. S., Miguez F. E., Laird D. A., Horton R., Westgate M. 2013. Assessing potential of biochar for increasing waterholding canarity of sandy snils. GCR Rinenergy, 5 (2): 132-143. https://doi.org/10.1111/gcbb.12026

Buhaiov V., Horenskyy V., Liatukiene A. 2018. The response of Medicago sativa to aluminium toxicity under laboratory and field conditions. Zemdirbyste-Aoriculture $105(2)$ 141-148. https://doi.org/10.13080/z-a.2018.105.018

Campos P., Miller A. L., Knicker H., Costa-Pereira M. F., Merino A., De la Rosa J. M. 2020. Chemical, physical and morphological properties of biochars produced from agricultural residues: implications for their use as soil amendment Waste Management, 105: 256-267. https://doi.org/10.1016/j.wasman.2020.02.013

Chakravarti I. M., Laha K. G., Koy J. 196\%. Handbook of Methods of Annlied Statisties, vol. I, n. 392-394 https://doi.org/10.1080/01621459.1968.11009335

Dias B. U., Silva C. A., Higashikawa F. S., Koig A., SánchezMonedero M. A. 2010. Use of biochar as bulking agent for the composting of poultry manure: effect on organic matter degradation and humification. Rinresource Terhnolnov 101 (4): 1239-1246. https://doi.org/10.1016/j.biortech.2009.09.024

Feng D., Zhao Y., Lhang Y., Xu H., Zhang L., Sun S. Zulr. Catalytic mechanism of ion-exchanging alkali and alkaline earth metallic species on biochar reactivity during $\mathrm{CO}_{2} / \mathrm{H}_{2} \mathrm{O}$ gasification Fuel 21) 5 53-53?

https://doi.org/10.1016/j.fuel.2017.10.045

Gao M., Li B., Yu A., Liang F., Yang L., Sun Y. 2010. The effect of aeration rate on forced-aeration composting of chicken manure and saxidust. Rinresource Technology 101 (6). 1899-1903. https://doi.org/10.1016/j.biortech.2009.10.027

Iqbal M., Nadeem A., Sherazi F., Khan K. 2015. Uptimization of process parameters for kitchen waste composting by response surface methodology. International Journal of Environmental Science and Technology, 12 (5): 1759-1768. https://doi.org/10.1007/s13762-014-0543-x

Jindo K., Suto K., Matsumoto K., Garcia C., Sonoki T. Sanchez-Monedero M. A. 2012. Chemical and biochemical characterisation of biochar-blended composts prepared from noultry manure Rinresource Technolnov 110· 396-404. https://doi.org/10.1016/j.biortech.2012.01.120

Jindo K., Sonoki I., Matsumoto K., Caneilas L., Roig A., Sanchez-Monedero M. A. 2016. Influence of biochar addition on the humic substances of composting manures. Waste Management, 49:545-552 https://doi.org/10.1016/j.wasman.2016.01.007

Khan N., Clark I., Sanchez-Monedero M. A., Shea S., Meier S. Bolan N. 2014. Maturity indices in co-composting of chicken manure and sawdust with biochar. Bioresource Technology $168 \cdot 245-251$ https://doi.org/10.1016/j.biortech.2014.02.123

Li K., Wang J. J., Zhang Z., Shen F., Zhang U., Uin R., Li X., Xiao R. 2012. Nutrient transformations during composting of pig manure with hentonite Rinresource Technology 121: 362-368. https://doi.org/10.1016/j.biortech.2012.06.065

Liu N., Zhou J., Han L., Ma S., Sun X., Huang G. 2017. Role and multi-scale characterization of bamboo biochar during poultry manure aerobic composting. Bioresource Technology 241: 100-109 https://doi.org/10.1016/j.biortech.2017.03.144

Luo W. H., Yuan J., Luo Y. M., Li G. X., Nghiem L. D., Price W. E. 2014. Effects of mixing and covering with mature compost on gaseous emissions during composting. Chemosnhere 117: 14-19

https://doi.org/10.1016/j.chemosphere.2014.05.043

Martins M. K., Sarkis L. F., Guareschi K. F., Santos C. A., Sant'Anna S. A. C., Zaman M., Jantalia C. P., Alves B. J. R., Boddey R. M., Araújo E. S., Urquiaga S. 2021. A simple and easy method to measure ammonia volatilization: accuracy under field conditions Pedosnhere, 31 (?): $755-264$ https://doi.org/10.1016/S1002-0160(20)60077-7

Nakhshiniev B., Perera C., Biddinika M. K., Gonzales H. B., Sumida H., Yoshikawa K. 2014. Reducing ammonia volatilization during composting of organic waste through addition of hydrothermally treated lignocellulose. International Rindeterinration and Rindegradation, 96: 58-62. https://doi.org/10.1016/j.ibiod.2014.08.011 
Oni B. A., Oziegbe O., Olawole O. O. 2019. Significance of biochar application to the environment and economy. Annals of A oricultural Sriences $64(?) \cdot 7 ? 2-236$. https://doi.org/10.1016/j.aoas.2019.12.006

Qasim W., Lee M. H., Moon B. E., Ukyere F. G., Khan F., Nafees M., Kim H. T. 2018. Composting of chicken manure with a mixture of sawdust and wood shavings under forced aeration in a closed reactor system. International Journal of Rerveling of Organir Waste in A griculture, 7 (3): 261-267. https://doi.org/10.1007/s40093-018-0212-z

Rong K., Zheng Y., Zhang F., Yang L., L1 Z. 2019. The effects of different types of biochar on ammonia emissions during co-composting poultry manure with a corn leaf. Polish Inurnal of Fnvirnnmental Studies 28 (5): 3837-3843. https://doi.org/10.15244/pjoes/95179

Sarkar B., Choi H. L., Zhu K., Mandal A., Biswas B., Suresh A. 2016. Monitoring of soil biochemical quality parameters under greenhouse spinach cultivation through animal waste recycling. Chemistry and Ecology 32 (5): 407-418. https://doi.org/10.1080/02757540.2016.1150457

Silva M. E., Lemos L. I., Cunha-Queda A. C., Nunes O. C. 2009. Co-composting of poultry manure with low quantities of carbon-rich materials Waste Management and Research, 77 (2): 119-128. https://doi.org/10.1177/0734242X08096693

Steiner C., Das K. C., Melear N., Lakly D. 20IU. Keducing nitrogen loss during poultry litter composting using biochar. Inurnal of Environmental Quality 39 (4): 1236-1242. https://doi.org/10.2134/jeq2009.0337

Tiquia S. M., Iam N. F. Y., Hodgkiss I. J. 1996. Effects of composting on phytotoxicity of spent pig-manure sawdust litter Fnvirnnmental Pollution 03 (3). 349-356 https://doi.org/10.1016/S0269-7491(96)00052-8

Vandecasteele B., Keubens B., Willekens K., De Neve S. 2014 Composting for increasing the fertilizer value of chicken manure: effects of feedstock on P availability. Waste and Rinmass Valorization, 5 (3) 4 491-503 https://doi.org/10.1007/s12649-013-9264-5

Vandecasteele B., Sinicco I., D'Hose I., Vanden Nest T., Mondini C. 2016. Biochar amendment before or after composting affects compost quality and $\mathrm{N}$ losses, but not $\mathrm{P}$ plant uptake Inurnal of Environmental Management 168 200-209. https://doi.org/10.1016/j.jenvman.2015.11.045
Višniauskė I., Barčauskaitė K., Bakšienė E., Mažeika R. 2018. Evaluation of contamination levels of different types of composts and their suitability for usage in agriculture. Zemdirhyste-A griculture, 105 (3): 211-220. https://doi.org/10.13080/z-a.2018.105.027

Volungevičius J., Feiza V., Amalevičiūtè-Volungè K., Liaudanskienè I., Šlepetienè A., Kuncevičius A., Vengalis R., Vèlius G., Prapiestienè R., Poškienè J. 2019. Transformations of different soils under natural and anthropogenized land management. ZemdirbysteA oriculture $106(1): 3-14$

https://doi.org/10.13080/z-a.2019.106.001

Wang Q., Awasth1 M. K., Zhang Z., Wong J. W. C. 2019. Sustainable composting and its environmental implications. Taherzadeh M. J. et al. (eds). Sustainable Resource Recovery and 7ern Waste Annroarhes Flsevier chanter 9 n 115-132. https://doi.org/10.1016/B978-0-444-64200-4.00009-8

Xiao K., Awasth1 M. K., L1 K., Park J., Pensky S. M., Wang Q., Wang J. J., Zhang Z. 2017. Recent developments in biochar utilization as an additive in organic solid waste composting: a review Rinresnurce Technolnov 746 703-7.13. https://doi.org/10.1016/j.biortech.2017.07.090

Zádorovà I., Skàia J., Žiżala D., Vanėk A., Penižek V. 2021. Harmonization of a large-scale national soil database with the World Reference Base for Soil Resources 2014. Genderma, 384 (6): 114819. https://doi.org/10.1016/j.geoderma.2020.114819

WRB 2014. World reterence base for soil resources World soil resnurces reports No. 106. http://www.fao.org/3/i3794en/ I3794en.pdt

Zainudin M. H., Mustapha N. A., Maeda T., Ramli N., Sakai K., Hassan M. 2020. Biochar enhanced the nitrifying and denitrifying bacterial communities during the composting of poultry manure and rice straw. Waste Management 106. 240-249 https://doi.org/10.1016/j.wasman.2020.03.029

Zhang L., Sun X. 2016. Influence of bulking agents on physical, chemical, and microbiological properties during the two-stage composting of green waste. Waste Management 48: 115-126. https://doi.org/10.1016/j.wasman.2015.11.032

\title{
Bioanglies ịterpimo būdo įtaka amoniako išgaravimui ir vištų mėšlo komposto kokybei
}

\author{
M. G. M. Abd El-Rahim ${ }^{1,2}$, S. Dou ${ }^{1}$, L. Xin ${ }^{1}$, S. Xie ${ }^{1}$, A. Sharaf ${ }^{1}$, A. Alio Moussa ${ }^{3}$, \\ M. A. Eissa ${ }^{4}$, A.-R. A. Mustafa ${ }^{5}$, G. A. M. Ali ${ }^{6}$, M. H. Hamed \\ ${ }^{1}$ Jilino žemès ūkio universiteto Išteklių ir aplinkos mokslų koledžas, Kinija \\ ${ }^{2} \mathrm{Al}$-Azhar universiteto Žemès ūkio fakultetas, Egiptas \\ ${ }^{3}$ Jilin žemès ūkio universiteto Augalų biotechnologijų centras, Kinija \\ ${ }^{4}$ Asiūto universiteto Žemès ūkio fakultetas, Egiptas \\ ${ }^{5}$ Sohag universiteto Žemès ūkio fakultetas, Egiptas \\ ${ }^{6} \mathrm{Al}$-Azhar universiteto Gamtos mokslu fakultetas, Egiptas \\ ${ }^{7}$ Naujojo slènio universiteto Žemès ūkio fakultetas, Egiptas
}

\section{Santrauka}

Vištų mėšlo kompostavimas daro neigiamą įtaką ekosistemai, nes didèja amoniako $\left(\mathrm{NH}_{3}\right)$ emisija. Mèšlo kompostavimo metu dalimis ịterptos bioanglies (Bi), gautos iš kukurūzų šiaudų, priedas gali paskatinti kompostavimo procesą, pagerinti pagaminto komposto kokybę ir sumažinti $\mathrm{NH}_{3}$ išsiskyrimą. Kompostavimo krūvoms sudaryti buvo sumaišytas šviežias vištų mèšlas ir kukurūzų šiaudai $(2: 1 \mathrm{~m} / \mathrm{m})$. Bioanglis $(10 \% \mathrm{~m} / \mathrm{m})$ i komposto krūvas buvo įterpta skirtingais būdais: vieną kartą $10 \%$ eksperimento pradžioje (OTABi) ir dalimis $2,5 \%$ kas 0, 3, 7 ir 15 kompostavimo dienų (SABi). $\mathrm{NH}_{3}$ emisija matuota vykdant stendinị kompostavimo eksperimentą. Siekiant ịvertinti komposto fitotoksiškumą ir branda, Petri lèkštelèse buvo atlikti daigumo bandymai. Palyginti su kontroliniu (be bioanglies) ir OTABi variantais, SABi turejjo teigiamą itaką (40 ir $33 \%$ ) komposto bendrosioms savybėms ir sumažino suminę $\mathrm{NH}_{3}$ emisija. Nors OTABi variantas paspartino komposto skaidymąsi, jis nepadidino humifikacijos. Subrendusio komposto SABi variante huminių medžiagų buvo 17 ir $40 \%$ daugiau nei kontroliniame ir OTABi variantuose. Be to, iterpus SABi, huminiu rūgščiu anglies ir humifikacijos indekso vertès buvo gerokai didesnès nei kitų variantų. Palyginti su kontroliniu variantu, kompostavimo pabaigoje abu bioanglies panaudojimo būdai pasižymèjo maža vandenyje tirpios organinès anglies koncentracija ir dideliu sėklų daigumo indeksu. Tyrimo duomenys rodo, kad, kompostuojant vištų mėšlą ir siekiant sumažinti azoto nuostolius, sušvelninti $\mathrm{NH}_{3}$ emisiją ir padidinti humifikaciją, bioanglies įterpimas dalimis yra labai svarbi praktika.

Reikšminiai žodžiai: daigumo indeksas, humifikacija, kompostavimo charakteristikos, $\mathrm{NH}_{3}$ išsiskyrimas. 